\title{
Leaders
}

\section{The genetics of inherited colon cancer}

Regional Genetic

Services,

Birmingham

Heartlands Hospital,

Birmingham

Y Wallis

F Macdonald

Correspondence to: Dr F Macdonald West Midlands Regional Genetic Services, DNA Laboratory, Birmingham Heartlands Hospital, Yardley Green Unit, Birmingham B9 5PX.

Accepted for publication 31 August 1995
DNA Laboratory,

\author{
Y Wallis, F Macdonald
}

Colorectal cancer accounts for approximately 20000 deaths per year in the UK and neither the morbidity nor the mortality have improved significantly in the past 50 years. None of the possible screening procedures have been shown to be both effective and inexpensive as well as acceptable to patients, and none has shown any decrease in mortality. One group of patients who can, however, be targeted immediately for screening are those known to be at high risk of

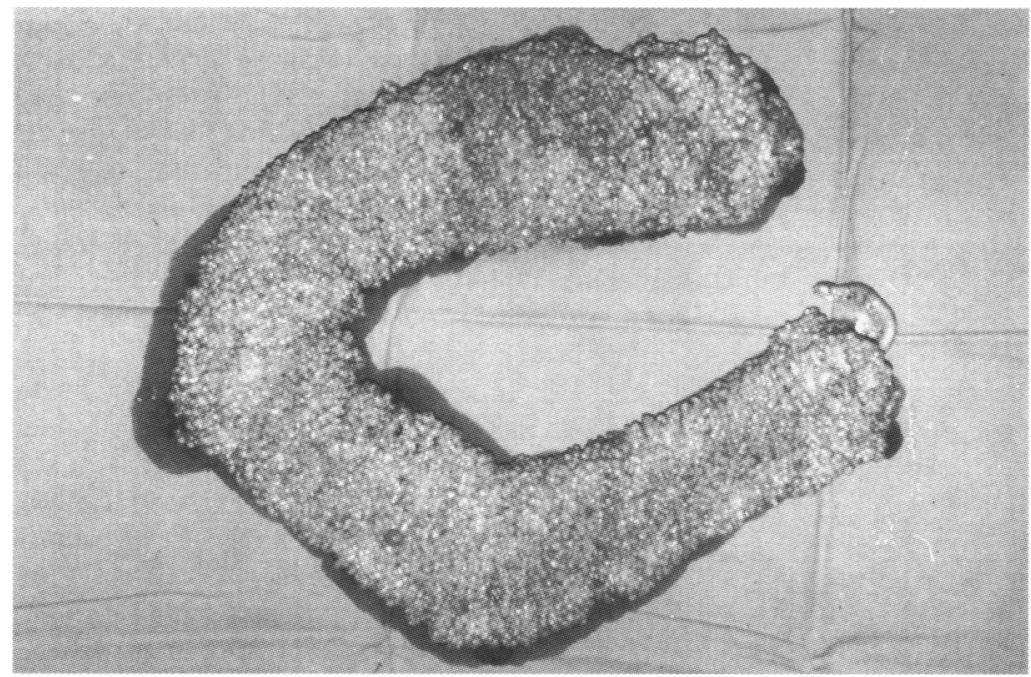

Figure 1 Colon from a 12 year old girl with FAP showing the surface of the mucosa carpeted with thousands of adenomatous polyps.

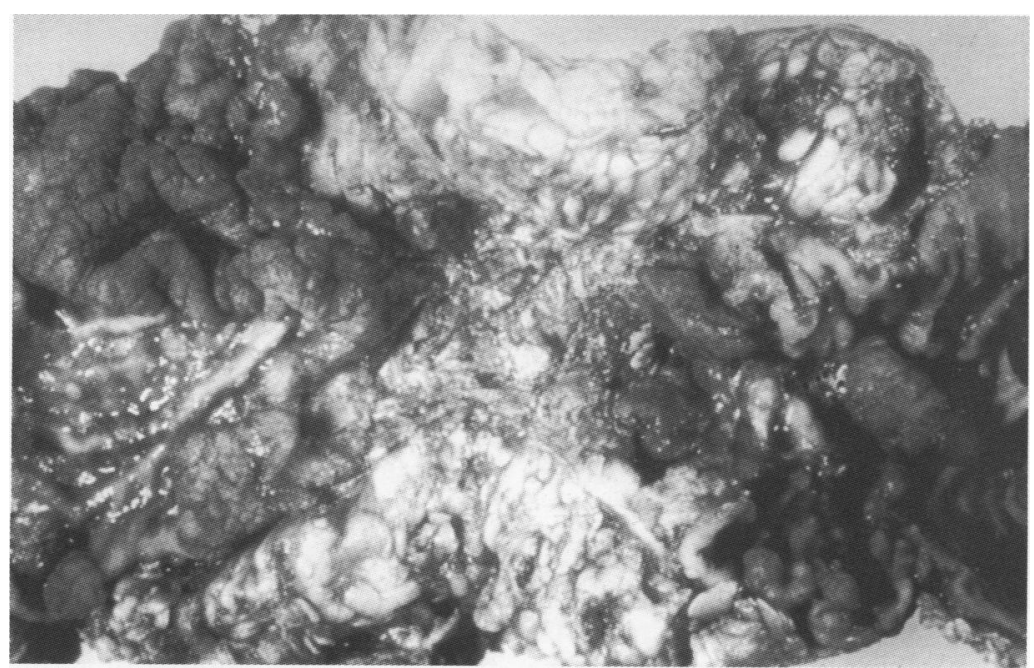

Figure $2 A$ resected colon from a 21 year old woman with FAP showing a Dukes' $C$ adenocarcinoma and multiple polyps. (Photograph courtesy of Dr $\mathcal{F}$ Newman,

Department of Histopathology, Birmingham Heartlands Hospital, Birmingham.

Reproduced from Oncogenes and Tumor Suppressor Genes (Macdonald and Ford), with permission of BIOS Scientific Publishers Ltd.
Table 1 Inherited conditions predisposing to colorectal cancer

Familial adenomatous polyposis

Hereditary non-polyposis colon cancer

(Lynch types 1 and 2, Muir-Torre syndrome)

Turcots syndrome

Peutz Jeger syndrome

Juvenile polyposis

Gorlin syndrome

developing colon cancer because of a familial predisposition to the disease. There are a number of conditions which predispose to colorectal cancer (table 1). In recent years two of these, familial adenomatous polyposis (FAP) and hereditary non-polyposis colon cancer (HNPCC), have been studied in detail, the causative genes isolated and mutations identified in the germline of affected individuals. This has enabled screening of high risk individuals to be carried out and prophylactic surgery performed before the development of malignant tumours. The genes associated with these inherited conditions have also been shown to play a role in the development of sporadic colon cancer, so that many of the molecular changes associated with non-inherited disease have begun to be more clearly defined. In this leader, the current understanding of the structure and function of these genes and their role in colorectal cancer is discussed.

\section{Familial adenomatous polyposis}

CLINICAL FAP

Familial adenomatous polyposis is a dominantly inherited predisposition to colorectal cancer. ${ }^{1}$ It has an incidence of approximately 1 in $10000^{2}$ and accounts for $1 \%$ of all cases of colorectal cancer. ${ }^{3}$ Affected individuals typically develop hundreds to thousands of adenomatous polyps in the colon and rectum usually before their 20th birthday (fig 1). ${ }^{1}$ Histologically, the vast majority of polyps are tubular adenomas, with only occasional polyps having villous features. ${ }^{1}$ Without treatment, at least one of these adenomas will progress to carcinoma (fig 2). ${ }^{4}$ The mean life expectancy of an untreated patient with FAP is 40 years, with death usually caused by metastatic colorectal cancer. ${ }^{4}$

Approximately $30-40 \%$ of FAP cases are caused by a new mutation ${ }^{5}$ and subsequently many already have cancer at the time of diagnosis. However, in FAP families, cancer may be prevented in siblings and first degree relatives of 


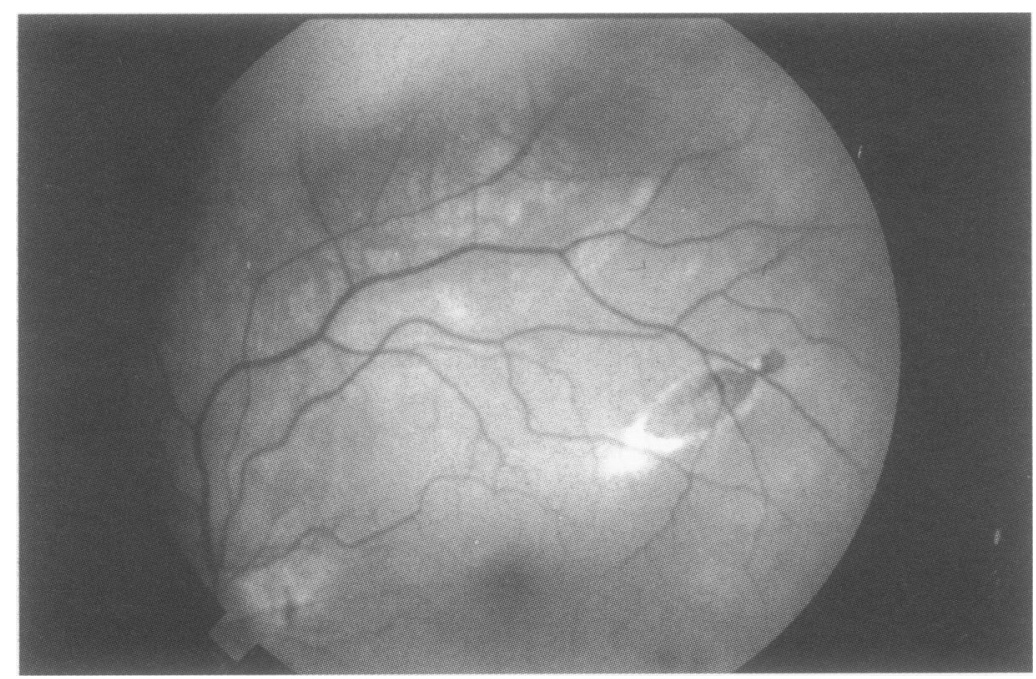

Figure 3 Congenital hypertrophy of the retinal pigment epithelium. Large pigmented lesion with a halo.

affected individuals by prophylactic colectomy immediately upon the detection of colonic disease. Until recently, the only available method for the early detection of affected individuals was to look directly for colonic disease by

\section{Family 1}
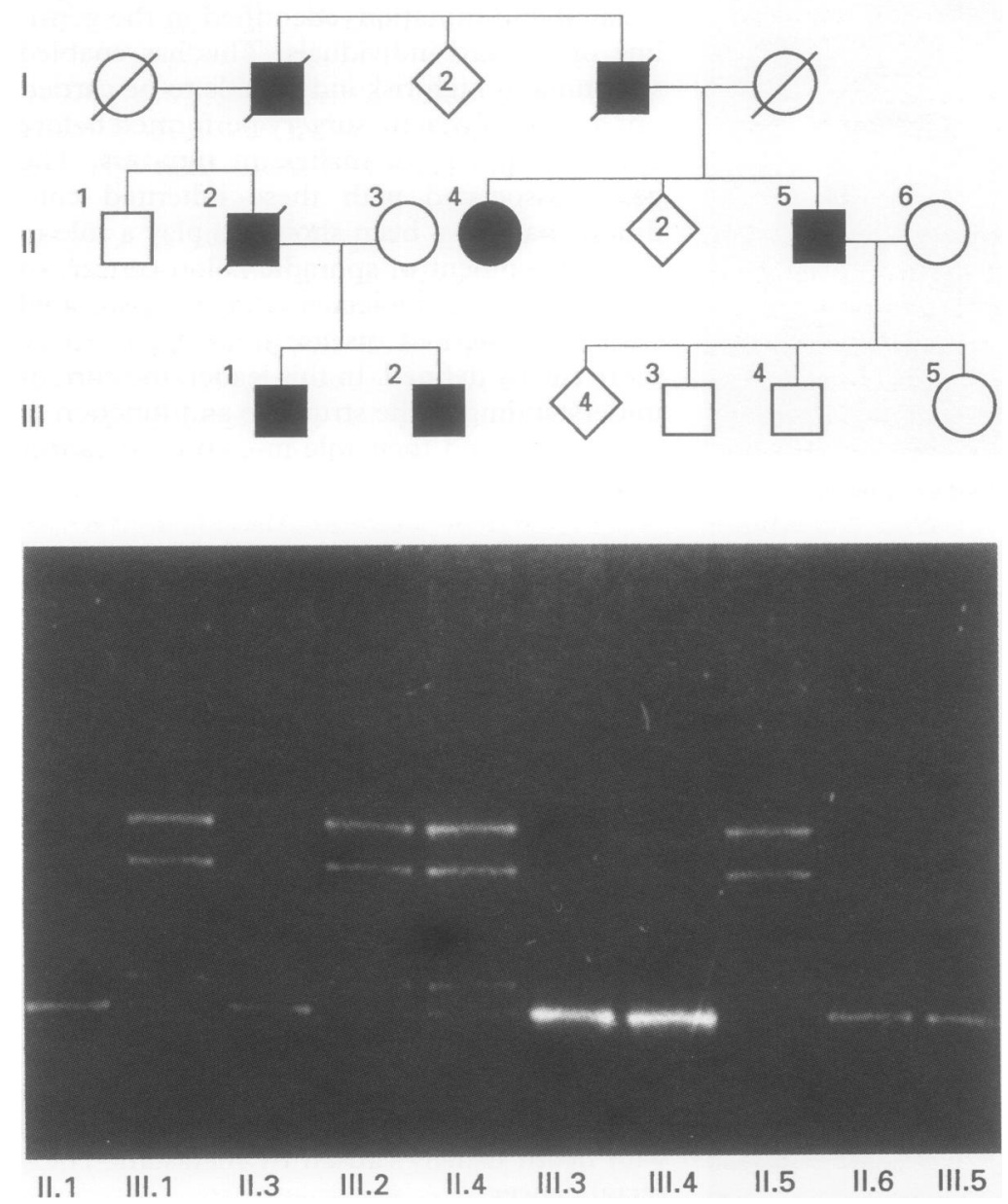

Figure 4 The top panel shows the pedigree of a FAP family. The lower panel shows the $D G G E$ results for exon 8 of the APC gene. Affected individuals III-1, III-2, II-4, and II-5 show a variant pattern, indicating the presence of a possible mutation which was II-5 show a variant pattern, indicating the presence of a possible mutation which was
subsequently confirmed by sequencing as a $C$ to $T$ transition at codon 283 . A normal pattern is seen in the "at risk" individuals, III-3, III-4 and III-5, indicating that they have not inherited the mutation present in their father. colonoscopy. The manifestations of FAP are not restricted to the colon and rectum and most patients exhibit both benign and malignant extracolonic features. Benign lesions most commonly include epidermoid cysts, ${ }^{6}$ osteomas, ${ }^{7}$ congenital hypertrophy of the retinal epithelium (CHRPE) (fig 3), ${ }^{8}$ desmoid tumours, ${ }^{9}$ and upper gastrointestinal polyps. ${ }^{10}$ Epidermoid cysts, osteomas and CHRPE lesions are present many years before the onset of colonic polyposis and may be used as clinical indicators of FAP gene carriers. ${ }^{112}$

In addition to colorectal cancer, patients with FAP are at an increased risk of developing other malignancies, including thyroid cancer, ${ }^{13}$ hepatoblastoma, ${ }^{14}$ gastric cancer, ${ }^{15}$ medulloblastoma, ${ }^{16}$ and carcinomas of the periampullary area, ${ }^{17}$ bile duct, ${ }^{18}$ and duodenum. ${ }^{19}$

GENETICS OF FAP

Constitutional mutations in the adenomatous polyposis coli gene (APC) are responsible for FAP. APC was localised to the long arm of chromosome 5 in 1986, when an interstitial deletion within 5q13-22 was detected cytogenetically in a mentally retarded patient with FAP. ${ }^{20}$ Genetic linkage to FAP was then confirmed using a polymorphic DNA marker known to map to 5q. In situ hybridisation using this probe narrowed the position of the APC gene to $5 \mathrm{q} 21-22 .^{2122}$ Several linked polymorphic DNA markers were discovered subsequently and used to track the inheritance of the disease gene in FAP families. ${ }^{23-25}$

Genetic linkage methodology may provide accurate risk estimates of gene inheritance, especially when markers from both sides of the gene are used. ${ }^{26}$ In the clinical setting the risk estimate given by linkage analysis will determine the appropriate level of colonic surveillance for individual patients with FAP.

Several genes within the 5q21-22 region were investigated as potential candidates for FAP before the APC gene was eventually isolated and sequenced in $1991 .{ }^{2728} \mathrm{APC}$ was the only gene in which germline transmission of mutations could be identified by DNA sequencing. ${ }^{2930}$ Since its isolation, a wide range of mutation detection systems have been used to analyse directly the APC coding region for disease-causing mutations in FAP families, giving $100 \%$ accurate presymptomatic diagnosis (fig 4). At risk individuals shown not to have a mutation by a direct test can be removed from any further colonic surveillance programmes. However, one group recommends that colon screening should be performed at three time points in mutation negative patients, to take account of the possibility of laboratory error. ${ }^{31}$

MUTATION ANALYSIS OF THE APC GENE

The APC protein is coded for by approximately 8500 bases of DNA. A large number of germline mutations in the APC gene have been identified worldwide. Mutations from 320 patients with FAP have been reviewed $\left(^{31-43}\right.$ and Wallis et al, unpublished data) and are 


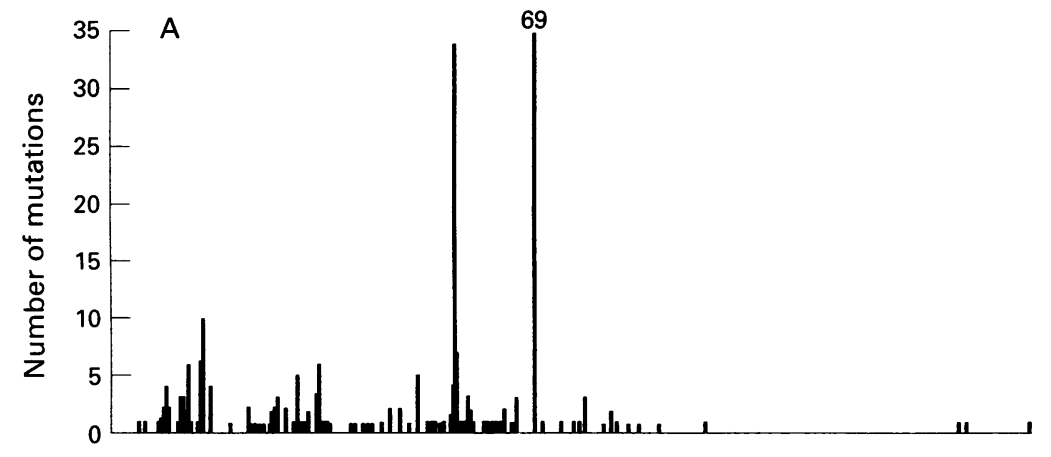

APC coding region (representing codons 1-2843)

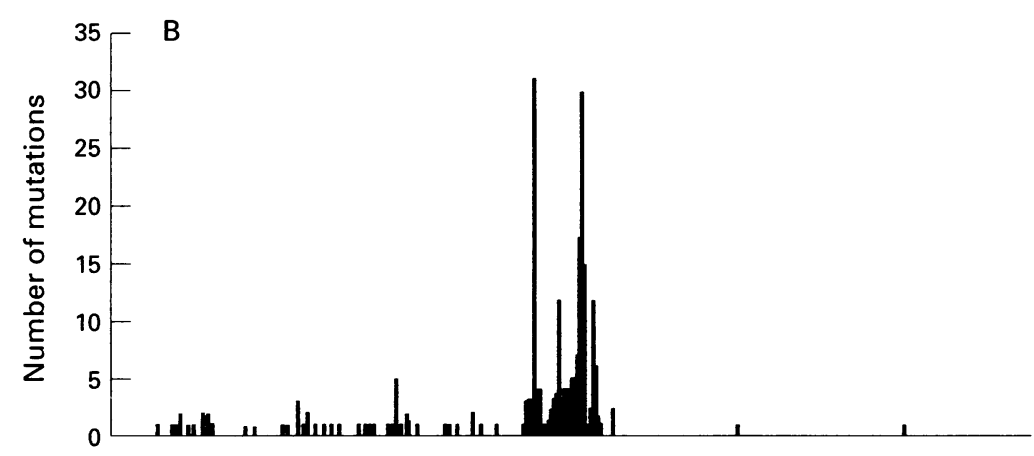

APC coding region (representing codons 1-2843)

Figure 5 (A) Number and distribution of germline mutations in the APC gene taken from ${ }^{31-43}$ and Wallis et al (unpublished data). The two main "hot spots" can be seen at codons 1061 (34 cases) and codons 1309 (69 cases). (B) Number and distribution of somatic mutations in the APC gene taken from ${ }^{4046}$ and ${ }^{49-51}$. The localisation of the majority of mutations to the mutation cluster region (codons 1280-1500) can be seen.

included in fig 5A. Even though mutations have been detected along the whole length of the gene, $98 \%$ of them are found over the first two thirds of the coding region (fig 5A). One third of the patients have mutations at two "hotspot" regions, both 5 base pair deletions, at codons 1061 and 1309 . Of the remaining 218 patients, 150 different APC mutations have been reported and of these, $80 \%$ are unique. Mutation studies have demonstrated that the predominant mode of inactivation is chaintermination. In the series of mutations shown in fig $5 \mathrm{~A}, 94 \%$ produced a premature stop codon, either directly by base substitution or indirectly by frameshift. Splice site mutations predicted to produce an abnormally sized protein product accounted for a further $4 \%$ of cases. It is still not completely clear whether amino acid changes identified in a small number of patients with FAP are true disease causing alterations, although in a number of cases such alterations have been the only changes found, even after sequencing the entire gene.

The heterogeneous distribution and nature of APC mutations makes direct detection of mutation of the gene itself a difficult task. Most APC mutation screening procedures involve the analysis of DNA segments amplified by the polymerase chain reaction (PCR). A variety of methodologies have been used for this purpose, including denaturing gradient gel electrophoresis (DGGE), single stranded conformational polymorphism, heteroduplex analysis, and RNase protection. However, a different approach, the protein truncation test (PTT), which takes advantage of the predominant chain-terminating mode of inactivation, has been used recently to detect mutation. ${ }^{445}$ In this test amplified segments of the APC gene are transcribed into RNA, which is then translated to protein. Both steps are carried out in vitro. A germline chain-terminating mutation will produce a truncated protein product, which can be detected by polyacrylamide gel electrophoresis (fig 6). The advantages of this technique are improved sensitivity and the ability to analyse the entire coding region in five overlapping PCR reactions, instead of the 40 or so required in more conventional methods.

\section{APC MUTATION DISTRIBUTION: GERMLINE VERSUS SOMATIC}

Somatic APC gene inactivation has been shown to play an early role in sporadic colorectal carcinogenesis. Mutations are identified in approximately $65 \%$ of adenomas and carcinomas even in tumours with a diameter of less than $0.5 \mathrm{~cm} .{ }^{46}$ Somatic inactivation of the second APC allele has also been implicated in the pathogenesis of FAP adenomas, where mutations are detected in up to $80 \%$ of these neoplasms. ${ }^{40448}$ A summary of 367 somatic APC mutations, identified in both FAP and sporadic tumours, is presented in fig $5 \mathrm{~B} .{ }^{404649-51}$ Like germline mutations, the majority (99\%) of somatic mutations occur within the first two thirds of the gene and more than $95 \%$ are chain-terminating.

However, a striking difference is seen between the distribution of germline and somatic mutations (figs 5A and 5B). More than $80 \%$ of somatic mutations occur between codons 1280 and 1500 , compared with only $25 \%$ of germline mutations. This region has been referred to as the mutation cluster region $(M C R)^{49}$ and it may be that a mutation within this region, in at least one APC allele, is necessary for growth advantage.

GENOTYPE-PHENOTYPE CORRELATIONS IN FAP In keeping with the theory that mutations in the MCR result in a greater propensity for tumour formation, three separate studies have correlated mutations within this region with severe colonic disease in FAP. A study from Japan $^{52}$ correlated profuse polyposis $(>5000$ polyps) with the occurrence of germline mutations between codons 1250 and 1464, whereas sparse polyposis $(<2000$ polyps) was seen in patients with mutations outside this region. Also, in 1994, Caspari et $a l^{53}$ and Gayther et $a l^{54}$ correlated a severe FAP colonic phenotype (polyp number, age of onset and age of death due to colorectal cancer) with the common 5 base pair deletion at codon 1309 .

At the other end of the spectrum, APC mutations in patients with an attenuated form of FAP, who develop fewer colonic polyps at a later age, have been shown to occur at the extreme proximal end of the gene. ${ }^{36}$ 


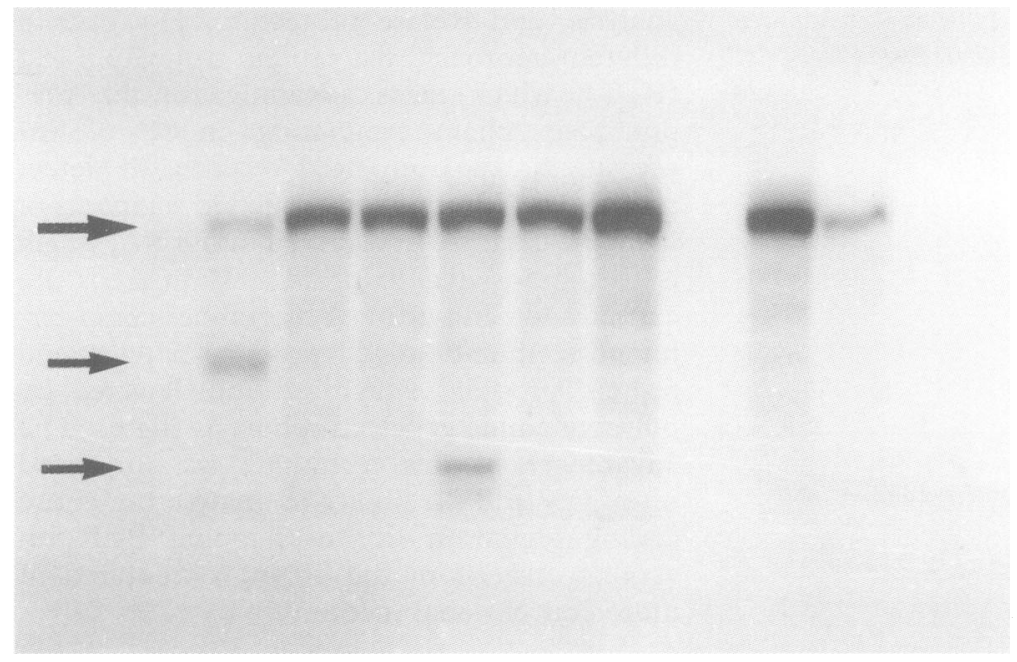

Figure 6 Protein Truncation Test. The protein product of the normal DNA fragment is indicated at the top of the gel (large arrow). Lanes 1 and 4 contain DNA samples from patients with chain-terminating mutations between codons 686 and 1217 (small arrows). No mutations are present in the DNA in other lanes. (Photograph courtesy of Steve McKay, Regional Genetic Services, Birmingham Heartlands Hospital, Birmingham.)

GENOTYPE-PHENOTYPE CORRELATIONS FOR EXTRACOLONIC MANIFESTATIONS

Both intra- and interfamilial differences in the expression of extracolonic manifestations (ECM) are seen in FAP. With the accumulation of mutation data researchers have striven to determine whether the APC mutation position may also be a factor in the variability of ECM expression.

A significant correlation has been made between the position of APC mutations and the manifestation of CHRPE, the retinal pigmentation present in up to $90 \%$ of patients with FAP which exhibits minimal intrafamilial variation. Mutation studies ${ }^{435-57}$ have shown that retinal lesions are always present in patients with mutations between codons 413 and 1387, whereas they are absent in patients carrying germline mutations outside this region. For newly diagnosed CHRPE positive patients, this correlation has reduced the region to screen for mutations to just $35 \%$ of the coding region, effectively halving the workload.

A further correlation between the position of the mutation and "desmoid tumours" has been determined in a recent study, in which $90 \%$ of patients with FAP with a mutation distal to codon 1445 were shown to possess these tumours. ${ }^{57}$

Human and murine studies suggest that the FAP phenotype is modified by other unlinked loci. In 1993, Paul et $a l^{58}$ described a wide spectrum of phenotypes in patients with FAP sharing identical APC mutations. In addition, the expression of the FAP-like phenotype in the Min mouse model, produced by a germline mutation in the murine APC homologue, ${ }^{59}$ is affected by different genetic backgrounds. The modifying effect has been linked to the MOM-1 (Modifier Of Min) locus on mouse chromosome $4,{ }^{60}$ a region corresponding to human chromosome $1 \mathrm{p} 35$. The gene for secretory type II phospholipase A2 (Pla2s) has recently been proposed as a candidate for MOM-1, in which high concentrations of the gene product correlate with a resistance to tumour formation. ${ }^{61}$
It can only be a matter of time before modifying loci are identified for human FAP.

The expression of different splice forms of the APC gene may also explain the variable phenotype seen in FAP. ${ }^{62}$ In particular, one splice variant has been identified that lacks exon 1 , a region known to be essential for homodimerisation and interactions with other proteins. ${ }^{6364}$

APC PROTEIN STRUCTURE-FUNCTION RELATIONS The cellular function of the APC protein remains elusive mainly because it has little sequence similarity to other proteins. ${ }^{28}$ Antibody studies have identified it as a cytoplasmic protein, expressed in the upper portions of epithelial colonic crypts, suggesting that it is functional in the mature colonocyte. ${ }^{65}$

Several structural features have been identified along the 2843 amino acid length. It is the aim of current research programmes to assign specific functions to these regions, to clarify both its normal cellular function as well as the mechanism of action of mutant truncated protein forms.

The first third of the APC protein contains a series of heptad repeat sequences predicted to form $\alpha$-helical structures, known to facilitate protein dimerisation. ${ }^{66}$ Protein-protein interactions may be a prerequisite for the normal function of this protein. In addition, the potential for dominant interference by the truncated mutant form has been demonstrated in vivo by wild-type-mutant associations. ${ }^{64}$

Two repeat regions within the middle third of the APC protein have recently been shown to associate with an adherens junction protein called $\beta$-catenin. ${ }^{67-69}$ Adherens junctions are required for cell adhesion and cytoskeletal integrity, thereby regulating normal cell growth and behaviour. ${ }^{70}$ The implications of this interaction are not exactly known. However, both a downstream targeting role for signaling by $\beta$ catenin has been proposed, as well as a regulatory role for APC, as interaction with the distal binding domain has been shown to downregulate the cytoplasmic $\beta$-catenin pool. ${ }^{69}$

Finally, the wild-type APC protein has recently been shown to associate with cytoplasmic microtubules. ${ }^{71}$ This activity is localised to a basic domain contained in the carboxyl-terminal region, and is therefore absent in mutant truncated molecules. The precise implications of this association are unclear, but microtubule polymerisation is known to be induced by APC molecules. ${ }^{72}$ It may be that the APC protein controls epithelial cell growth by serving as a link between the catenin molecules and the microtubule cytoskeleton.

\section{Hereditary non-polyposis colon cancer}

Hereditary non-polyposis colon cancer accounts for about $5-10 \%$ of all colorectal cancer. Like FAP, it is an autosomal, dominantly inherited condition. Tumours develop slightly later in life than in FAP, with a mean age of diagnosis of 40-45 years, and are found predominantly in the proximal, rather than the 
distal, colon. Although adenomas are found in the colons of patients with HNPCC, the numbers are similar to those seen in the general population. Synchronous and metachronous tumours are seen in $20-30 \%$ of patients. Unlike FAP, the diagnosis cannot be made on an isolated affected individual but is based instead on family history. The "Amsterdam Criteria" are used to diagnose HNPCC and include: (1) at least three relatives must have histologically proven colorectal cancer; (2) one relative must be a first degree relative of another; (3) at least two generations should be affected; and (4) cancer should be diagnosed under 50 years of age. FAP should be excluded. ${ }^{73}$

HNPCC can be divided into three related syndromes. Colon cancer is the only malignancy seen in Lynch Type 1 or site specific colon cancer. Lynch type 2 disease includes colon cancer along with endometrial, ovarian, small bowel, stomach, hepatobiliary, or transitional cell tumours of the urinary tract. ${ }^{74} \mathrm{Re}$ cently, it has been shown that Muir-Torre syndrome is also part of the HNPCC phenotype. ${ }^{75}$ In this condition, patients have sebaceous gland tumours and other skin cancers such as keratoacanthomas, as well as the spectrum of tumours seen in Lynch type 2 disease.

Until 1993, monitoring of individuals at risk of developing HNPCC depended on regular surveillance by colonoscopy or ultrasound where appropriate. Over the past two years, the localisation and subsequent isolation of the causative genes for the disorder has meant that molecular methods can be used to identify those at high risk so that they can be closely monitored whereas those at low risk could be removed from the screening programme completely or at least have less frequent investigations.

MAPPING OF THE HNPCC GENES

The initial chromosomal localisation of a gene for HNPCC was achieved by studying two large pedigrees with 345 different microsatellite markers scattered throughout the genome. Cosegregation of the disease was eventually obtained with a marker which mapped to the short arm of chromosome 2 at $2 \mathrm{p} 15 .{ }^{76}$ Fourteen other families were also studied and at least eight of these showed no evidence of linkage, suggesting the presence of genetic heterogeneity in HNPCC. This was confirmed when a second locus was localised on $3 \mathrm{p} 21 .{ }^{77}$ Preliminary evidence from linkage studies suggested that these two genes accounted for the majority, but not all cases, of HNPCC. ${ }^{78}$

GENOMIC INSTABILITY IN HNPCC

An interesting observation was made when the tumours of HNPCC patients were studied. ${ }^{79}$ A form of genomic instability was noted when DNA from normal tissues was compared with DNA extracted from the tumour of the same patient. Tumour DNA showed widespread alterations in short repeated sequences (microsatellites) distributed throughout the genome. These were seen as additional bands over and
Table 2 A comparison of mismatch repair genes in bacteria, yeast and humans

\begin{tabular}{lll}
\hline Bacteria & Yeast & Human \\
\hline MutS & MSH2 & hMSH2 \\
MutL & MLH1 & hMLH1 \\
MutL & PMS1 & hPMS1 \\
MutL & PMS2 & hPMS2 \\
\hline
\end{tabular}

above the usual one or two alleles identified in the normal tissue DNA. The finding suggested that replication errors, caused by slippage of DNA polymerase, had occurred during tumour development and had not been repaired. This phenotype, termed RER+ (for replication error positive), was found irrespective of the causative gene in a family.

The mechanism underlying this observation was suggested by previous studies of bacteria and yeast, where it had been shown that defects in mismatch repair genes resulted in instability of short repeated sequences. The best studied mismatch repair system is the DNA adenosine methylase (DAM)-instructed MutHLS pathway in Escherichia coli. ${ }^{80}$ This pathway is responsible for repair of nucleotide mispairing and occurs by recognition of mismatches by the mutS, mutL and mutH proteins, excision of the region of DNA containing the mismatch and subsequent resynthesis of the DNA. In Saccharomyces cerevisiae, an increase in destabilisation of repetitive DNA of up to 700fold is caused by mutations in genes of the yeast mismatch repair pathway. ${ }^{81}$ The bacterial and yeast genes involved in mismatch repair are shown in table 2 .

The association between mismatch repair and instability in bacterial and yeast systems suggested that a similar defect in a repair mechanism may be the cause of the instability seen in HNPCC and led to cloning of the genes for HNPCC.

\section{HNPCC GENES}

The strong homology between the human and yeast genes was used by one group to isolate the first of the HNPCC genes. Fishel et $a l^{82}$ mapped the human homologue of $\mathrm{MSH} 2$, called $\mathrm{hMSH} 2$, to chromosome $2 \mathrm{p} 15$, the region previously implicated by linkage analysis to contain a HNPCC gene. Leach $e t$ al ${ }^{83}$ used a more traditional positional cloning approach and also identified the same gene. In order to confirm that hMSH 2 was indeed the causative gene, both groups were able to show mutations within conserved regions of this gene in HNPCC families. A second human mismatch repair gene, hMLH1, was shown to map to 3 p21 implicating it as the second gene involved in HNPCC. ${ }^{84}$ Again, mutations in this gene were found in HNPCC families. ${ }^{85}$ Two further human homologues of the mutL gene-hPMS1 and hPMS2 - were also found to be mutated in HNPCC families, ${ }^{86}$ thereby implicating four genes in the pathogenesis of HNPCC (table 1). The hMSH 2 gene causes around $60 \%$ of cases of HNPCC, hMLH1 causes around $30 \%$ and the other two together are the causative genes in the remainder (unpublished data, 
Table 3 Human mismatch repair genes which cause HNPCC

\begin{tabular}{llll}
\hline Gene & Location & $\begin{array}{l}\text { Size } \\
\text { (base pairs) }\end{array}$ & $\begin{array}{l}\text { Protein size } \\
\text { (number of amino acids) }\end{array}$ \\
\hline hMSH2 & 2p21 & 2727 & 909 \\
hMLH1 & 3p21 & 2268 & 756 \\
hPMS1 & $2 \mathrm{q} 31-33$ & 2795 & 932 \\
hPMS2 & $7 \mathrm{p} 22$ & 2586 & 862 \\
\hline
\end{tabular}

Eurofap meeting, Budapest 1994). However, the exact figures may vary from one centre to another and are still based on relatively small numbers of families.

The structure and size of the four genes are now known (table 3) and germline mutations have been identified. ${ }^{8387-89}$ Mutation detection in the HNPCC genes has the same problems associated with detection of mutations in APC, further compounded by the fact that four genes rather than one are involved. As with APC, the mutations are to be found widely distributed throughout the genes, with the majority being either point mutations or small insertions or deletions. Most mutations are truncating, that is to say introduce premature stop codons, so that the PTT technique, used to detect mutation in APC, is a useful initial screening method for HNPCC. ${ }^{8586}$ Methodologies similar to those used to screen APC are also useful for a more exhaustive search (fig 7), particularly to identify missense mutations which would be missed by PTT. The majority of mutations are different in each family. Papadopoulos et al ${ }^{85}$ identified a 165 base pair deletion in seven kindreds of Finnish origin, but at least five of these could be traced back to a common

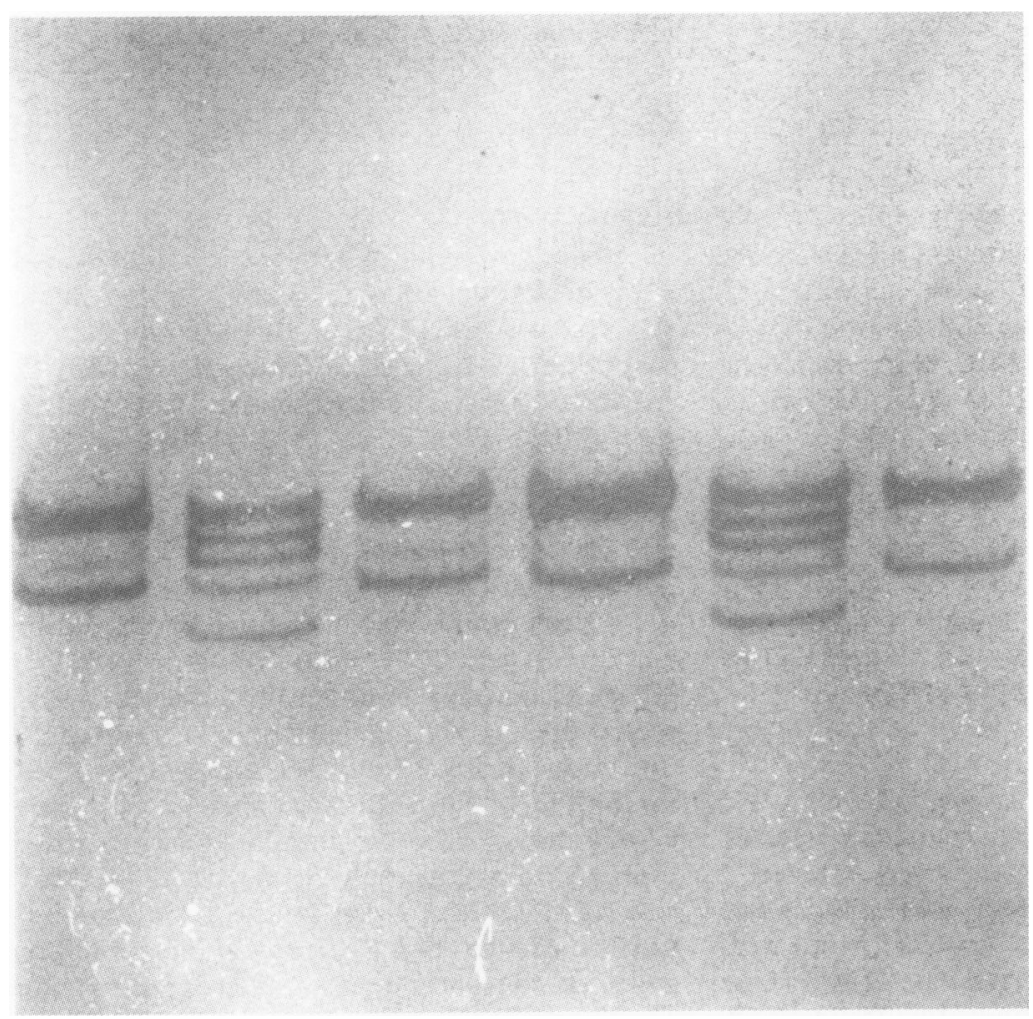

Figure 7 Silver stained single strand conformation polymorphism gel of members of a large family with Muir-Torre syndrome with a two base pair deletion in exon 12. Affected individuals are in lanes 2 and 5. (Photograph courtesy of Steve McKay, Regional Genetic Services, Birmingham Heartlands Hospital, Birmingham.) ancestor. An exon 5 splice site mutation has been found in four of 33 British families and is therefore the commonest mutation so far. ${ }^{90}$

Environmental as well as genetic factors, such as modifier genes, are likely to be involved in determining the phenotype. For example, two mutations in exon 12 of MSH2 have been identified in two families with Muir-Torre syndrome but exon 12 mutations have also been found in classic $\mathrm{HNPCC}^{87}$ without the association of skin tumours. To date, no genotype-phenotype correlations have been made and it is not even possible to identify which gene might be causative in a particular family from the clinical information.

\section{MODE OF ACTION OF THE HNPCC GENES}

Many of genes involved in carcinogenesis are tumour suppressors characterised by loss of heterozygosity ( $\mathrm{LOH})$ in tumours as classically described by Knudson for retinoblastoma. ${ }^{91}$ Initially, there was no evidence of $\mathrm{LOH}$ at either 2 p 15 or $3 \mathrm{p} 21$, suggesting that the mismatch repair genes acted via a different mechanism. However, it is now clear that HNPCC does in fact follow a version of the Knudson two hit hypothesis from a number of lines of evidence. Analysis of a limited number of tumours from individuals with germline mutations in MSH2, MLH1 or PMS1 demonstrated the presence of a somatic mutation in the second copy of the gene..$^{838692}$ Cell lines with a mutation in only one copy of $\mathrm{MSH} 2$ were shown to be proficient in mismatch repair, ${ }^{93}$ whereas those lines with deficiencies in mismatch repair have been shown to be hemizygous for a mutation in $\mathrm{MSH} 2$ or MLH $1 .{ }^{94}$ Recently, loss of the wild-type allele was found in up to $25 \%$ of tumours from patients with germline mutations in MLH $1 .{ }^{95}$ All of these studies suggest that inactivation of both alleles is necessary for tumorigenesis.

Two studies have shown how mutations in the mismatch repair genes might lead to the development of cancer by demonstrating that loss of these genes leads to a general mutator phenotype. In other words, mutations in the mismatch repair genes results in a higher than normal mutation rate allowing the accumulation of mutations in other genes such as tumour suppressor genes or oncogenes. ${ }^{9697}$

\section{MISMATCH REPAIR GENES IN SPORADIC COLON} CANCER

Replication errors have also been identified in sporadic colon cancer as well as other tumours including endometrial, breast, prostatic, pancreatic, stomach, and lung tumours. Between 12 and $25 \%$ of colorectal tumours are RER.$+^{79989}$ These tumours showed many of the features of HNPCC lesions in that they were frequently diploid or near diploid and occurred in the right side of the colon. Patients with replication errors at more than one microsatellite marker also showed a significant increase in survival. ${ }^{100}$ Preliminary results on very small numbers of tumours have suggested that replication errors become evident early in the 
development of colorectal cancer. ${ }^{98101}$ Young et $a l^{102}$ studied a much larger series of $46 \mathrm{ad}-$ enomas but could find no evidence of instability. Also, it was shown recently that the only adenomas with replication errors were those with foci of carcinoma in situ, suggesting that the errors are manifest at the adenomacarcinoma transition. ${ }^{103}$

In general, patients with RER + sporadic colorectal tumours do not have germline mutations in the mismatch repair genes. A recent study has demonstrated that patients with colorectal cancers diagnosed over 35 years of age showed instability in only $12 \%$ of tumours. In contrast, $58 \%$ of patients with cancer under 35 years of age had RER + tumours. Close to $50 \%$ of these young patients have been shown to have germline mutations in mismatch repair genes, ${ }^{104}$ a result which has important implications for genetic testing and subsequent management of their children.

\section{Summary}

Over the past five years, considerable progress has been made in the study of the genes involved in inherited colon cancer syndromes. These advances have also resulted in important findings for sporadic colon cancer. The identification of the causative genes for FAP and HNPCC has enabled presymptomatic diagnosis to be carried out routinely. High risk individuals are therefore targeted for screening preventing the unnecessary development of cancers and early death in these families. The identification of genes associated with HNPCC means that it will now become possible to look at a broader group of patients, apart from those who fulfil strict diagnostic classifications, to determine whether this syndrome is more common than previously thought. It also enables us to look for low penetrance mutations which may be responsible for apparently sporadic disease.

Dietary intervention studies are already underway in those patients at high risk of developing FAP and gene therapy studies can now be considered. A similar situation should soon become possible for HNPCC. The next five years should therefore be even more exciting than the past.

1 Bussey HJR. Familial polyposis coli: family studies, histopathology, differential diagnosis and results of treatment. Baltimore: Johns Hopkins University Press, 1975.

2 Reed TE, Neale JV. A genetic study of multiple polyposis of the colon. Am f Hum Genet 1955;7:236-63.

3 Mecklin JP. Frequency of hereditary colorectal carcinoma Gastroenterology 1987;93:1021-5.

4 Bulow S. Familial adenomatous polyposis. Danish Med $\mathcal{f}$ 1987;34:1-15.

5 Bulow S, Holm NV, Hauge M. The incidence and prevalence of polyposis coli in Denmark. Scand $\mathcal{F}$ Soc Med 1986;14:67-74

6 Gardner EJ, Plenk HP. Hereditary pattern for multiple osteomas in a family group. Am 7 Hum Genet 1952;4: $31-36$.

7 Gardner EJ, Richards RC. Multiple cutaneous and subcutaneous lesions occurring simultaneously with hereditary polyposis and osteomatosis. Am $\mathcal{f}$ Hum Genet 1953;5:139-47.

8 Blair NP, Trempe CL. Hypertrophy of the retinal pigment epithelium associated with Gardner's syndrome. $A m \mathcal{F}$ Opithelium associated with

9 McAdam WAF, Goliger JC. The occurrence of desmoids in patients with familial polyposis coli. $\mathrm{Br} \mathcal{F}$ Surg 1970; 57:618-31.
10 Burt RW, Berenson MM, Lee RG, Tolman KG, Freston JW, Gardner EJ. Upper gastointestinal polyps in Gardner's syndrome. Gastroenterology 1984;86:295-301.

11 Burn J, Church W, Chapman PD, Gunn A, Delhanty J, Roberts DF. A regional register for familial adenomatous polyposis: congenital hypertrophy of the retinal pigment popithelium as a means of carrier detection (abstract). $\mathcal{F}$ Med Genet 1989;26:207.

12 Morton DG, Gibson J, Macdonald F, Brown R, Haydon $\mathrm{J}$, Cullen R, et al. Role of congenital hypertrophy of the retinal pigment epithelium in the predictive diagnosis of familial adenomatous polyposis. $\mathrm{Br} \mathcal{F}$ Surg 1992;79. 689-93.

13 Thompson JS, Harned RK, Anderson JC, Hodgson PE Papillary carcinoma of the thyroid and familial polyposis coli. Dis Colon Rectum 1983;26:583-5.

14 Bussey HJR. Familial polyposis coli and hepatocellular neoplasms. Hepatology 1990;1:175-6.

15 Kurtz RC, Sternberg S, Miller HH, Decosse JJ. Upper gastrointestinal neoplasia in familial polyposis. Dis $S_{c i}$ gastrointestinal neo

16 Kropilac M, Jagelman DG, Fazio DW, Lavery IL, McGannon E. Brain tumours in familial adenomatous polyposis Dis Colon Rectum 1989;32:778-82.

17 Jagelman DG, DeCosse JJ, Bussey HJR. Upper gastrointestinal cancers in familial adenomatous polyposis. Lancet 1988;i:1149-51.

18 Jarvinen HJ, Nyberg M, Peltokallio P. Upper gastrointestinal polyps in familial adenomatous coli. Gut 1983, 24:333-9.

19 Spigelman AD, Williams CB, Talbot IC, Domizio P, Phillips RK. Upper gastrointestinal cancer in patients with familial adenomatous polyposis. Lancet 1989;ii:783-5.

20 Herrera L, Kakati S, Gibas L, Pietrzak E, Sandberg AA Brief clinical report: Gardner's syndrome in a man with an interstitial deletion of $5 \mathrm{q}$. Am $\mathcal{F}$ Med Genet 1986;25 473-6.

21 Leppert M, Dobbs M, Scambler P, O'Connell P, Nakamura $\mathrm{Y}$, Stauffer $\mathrm{D}$, et al. The gene for familial polyposis coli maps to the long arm of chromosome 5. Science 1987; 238:1411-13.

22 Bodmer WF, Bailey CJ, Bodmer J, Bussey HJR, Ellis A Gorman P, et al. Localisation of the gene for familial adenomatous polyposis within a small region of chromosome 5. Nature 1987;328:614-16.

23 Nakamura $Y$, Lathrop M, Leppert M, Dobbs M, Wasmuth $\mathrm{J}$, Wolff $\mathrm{E}$, et al. Localisation of the genetic defect in familial adenomatous polyposis within a small region of chromosome 5. Am f Hum Genet 1988;43:638-44.

24 Macdonald F, Morton DG, Rindl PM, Haydon J, Cullen $\mathrm{R}$, Gibson J, et al. Predictive diagnosis of familial adenomatous polyposis with linked DNA markers: population based study. BMF 1992;304:869-72.

25 Maher ER, Barton DE, Slatter R, Koch DJ, Jones $M H$ Nagase $\mathrm{H}$, et al. Evaluation of molecular genetic diagnosis in the management of familial adenomatous polyposis coli: a population based study. $f$ Med Genet 1993;30 675-8.

26 Olschwang S, Laurent-Puig P, Melot T, Thuille B, Thomas $\mathrm{G}$. High resolution genetic map of the adenomatous polyposis coli gene (APC) region. Am $\mathcal{F}$ Med Genet 1995 56:413-19.

27 Joslyn G, Carlson M, Thliveris A, Albertsen H, Groden J Stevens J, et al. Identification of deletion mutations and three new genes at the familial polyposis locus. Cell 1991 66:601-13.

28 Kinzler KW, Nilbert C, Vogelstein B, Bryan TM, Levy $\mathrm{DB}$, Smith $\mathrm{KJ}$, et al. Identification of a gene located at chromosome $5 \mathrm{q} 21$ that is mutated in colorectal cancers. Science 1991;251:1366-70.

29 Groden J, Thliveris A, Samowitz W, Carlson M, Gelbert $\mathrm{L}$, Albertsen $\mathrm{H}$, Joslyn $\mathrm{G}$, et al. Identification and characterisation of the familial adenomatous polyposis coli gene. Cell 1991;66:589-600.

30 Nishisho I, Nakamura Y, Miyoshi Y, Miki Y, Ando $H$, Horii $\mathrm{A}$, et al. Mutations of chromosome $5 \mathrm{q} 21$ genes in FAP and colorectal cancer patients. Science 1991;253: 665-9.

31 Petersen GM, Francomano C, Kinzler K, Nakamura Y. Presymptomatic direct detection of adenomatous polyposis coli (APC) gene mutations in familial adenomatous polyposis. Hum Genet 1993;91:307-11.

32 Fodde R, van der Luijt R, Wijnen J, Tops C, van der Klift H, van Leeuwen-Cornelisse I, et al. Eight novel inactivating germ line mutations at the APC gene iden-
tified by denaturing gradient gel electrophoresis. Gen-

33 Miyoshi Y, Ando H, Nagase H, Nishisho I, Horii A, Miki $\mathrm{Y}$, et al. Germ line mutations of the APC gene in 53 familial adenomatous polyposis patients. Proc Natl Acad Sci USA 1992a;89:4452-6.

34 Groden J, Gelbert L, Thliveris A, Nelson L, Robertson M, Joslyn G, et al. Mutational analysis of patients with adenomatous polyposis: identical inactivating mutations in unrelated individuals. Am $\mathcal{F}$ Hum Genet 1993a;52: in unrelatec $263-72$.

35 Olschwang S, Laurent-Puig P, Groden J, White R, Thomas $\mathrm{G}$. Germ-line mutations in the first 14 exons of the adenomatous polyposis coli (APC) gene. Am $f$ Hum Genet 1993a;52:272-9.

36 Spirio L, Olschwang S, Groden J, Robertson M, Samowitz W, Joslyn G, et al. Alleles of the APC gene: an attenuated W, Joslyn G, et al. Alleles of the APC gene: an at
form of familial polyposis. Cell 1993;75:951-7.

37 Varesco L, Gismondi V, James R, Robertson M, Grammatico P, Groden J, et al. Identification of APC gene mut- 
ations in Italian adenomatous polyposis coli patients by PCR-SSCP analysis. Am 7 Hum Genet 1993;52:280-5.

38 Gebert JF, Hahn M, Kadmon M, Herfarth C, Schackert HK. Identification of a germline mutation in a FAP HK. Identification of a germline mutation in a

39 Mandl M, Paffenholz R, Freidl W, Caspari R, Sengteller M, Propping P. Frequency of common and novel inactivating APC mutations in 202 families with familial adenomatous polyposis. Human Molecular Genetics 1994;3 $181-4$

40 Miyaki M, Konishi M, Kikuchi-Yanoshita R, Enomoto M, Igara $\mathrm{T}$, Muraoka $\mathrm{M}$, et al. Characteristics of somatic mutations of the adenomatous polyposis gene in colorectal tumours. Cancer Res 1994;54:3011-20.

41 Paffenholz R, Mandl M, Caspari R, Sengteller M, Propping $P$, Friedl W. Eleven novel germline mutations in the adenomatous polyposis coli (APC) gene. Human Moadenomatous polyposis coli (A

42 Stella A, Montera M, Resta N, Marchese C, Susca F, Gentile $M$, et al. Four novel mutations of the APC (adenomatous polyposis coli) gene in FAP patients. Human Molecular Genetics 1994;3:1687-8.

43 Wallis Y, Macdonald F, Morton D, McKeown C, Fodde $\mathrm{R}$, van der Luijt $\mathrm{R}$, et al. Identification of constitutional APC mutations in FAP families. International fournal of Colorectal Diseases 1994;9:57.

44 Powell SM, Petersen GM, Krush AJ, Booker S, Jen J, Giardiello FM, et al. Molecular diagnosis of familial
adenomatous polyposis. N Engl f Med 1993;329:1982-7.

45 Van der Luijt R, Khan PM, Vasen H, van Leeuwen C, Tops C, Roest P, et al. Rapid detection of translationterminating mutations at the adenomatous polyposis coli (APC) gene by direct protein truncation test. Genomics 1994;20:1-4.

46 Powell SM, Zilz N, Beazer-Barclay Y, Bryan TM, Hamilton SR, Thibodeau SN, et al. APC mutations occur early during colorectal carcinogenesis. Nature 1992;359:235-7.

47 Ichii S, Horii A, Nakaksuru S, Furuyama J, Utsunomiya J, Nakamura Y. Inactivation of both APC alleles in an early stage of colon adenomas in a patient with familial adenomatous polyp

48 Levy DB, Smith KJ, Beazer-Barclay Y, Hamilton SR, Vogelstein B, Kinzler KW. Inactivation of both APC alleles in human and mouse tumours. Cancer Res 1994 54:5953-8.

49 Miyoshi Y, Nagase H, Ando H, Horii A, Ichii S, Nakatsuru $\mathrm{S}$, et al. Somatic mutations of the APC gene in colorectal tumours: mutation cluster region in the APC gene. Human Molecular Genetics 1992b;1:229-33.

50 Ichii S, Takeda S, Horii A, Nakatsuru S, Miyoshi Y, Emi $M$, et al. Detailed analysis of genetic alterations in colorectal tumours from patients with and without familial adenomatous polyposis (FAP). Oncogene 1993;8 2399-405.

51 De Benedetti L, Sciallero S, Gismondi V, James R, Bafico A, Biticchi R, et al. APC gene mutations and histological characteristics of colorectal adenomas. Cancer Res 1994 54:3553-6.

52 Nagase H, Miyoshi Y, Horii A, Aoki T, Ogawa M, Utsunomiva $\mathrm{J}$, et al. Correlation between the location of sunomiya $\mathrm{J}$, et al. Correlation between the location of germ-line mutations in the APC gene and the number
of colorectal polyps in familial adenomatous polyposis patients. Cancer Res 1992;52:4055-7.

53 Caspari R, Friedl W, Mandl M, Möslein G, Kadmon $M$, Knapp $M$, et al. Familial adenomatous polyposis: mutation at codon 1309 and early onset of colon cancer. Lancet 1994;343:629-32.

54 Gayther SA, Wells D, SenGupta SB, Chapman P, Neale $\mathrm{K}$, Tsioupra K, et al. Regionally clustered APC mutations are associated with a severe phenotype and occur at a high frequency in new mutation cases of adenomatous high frequency in new mutation cases of adenomatous

55 Olschwang S, Tiret A, Laurent-Puig P, Muleris M, Parc $R$, Thomas $G$. Restriction of ocular fundus lesions to a specific subgroup of APC mutations in adenomatous polyposis coli patients. Cell 1993b;75:959-68.

56 Wallis YL, Macdonald F, Hultén M, Morton JEV, McKeown CM, Neoptolemos JP, et al. Genotype-phenotype correlation between position of constitutional APC gene mutation and CHRPE expression in FAP. Hum Genet 1994;5:543-8.

57 Caspari R, Olschwang S, Friedl W, Mandl M, Boisson C, Böker $\mathrm{T}$, et al. Familial adenomatous polyposis: desmoid tumours and lack of opthalmic lesions (CHRPE) astumours and lack of opthalmic lesions (CHRPE) as-
sociated with APC mutations beyond codon 1444 . sociated with APC mutations beyond

58 Paul P, Letteboer T, Gelbert L, Groden J, White R, Coppes MJ. Identical APC exon 15 mutations result in a variable phenotype in familial adenomatous polyposis. Human Molecular Genetics 1993;2:925-31.

59 Su L-K, Kinzler KW, Vogelstein B, Presinger AC, Moser $\mathrm{AP}$, Luongo $\mathrm{C}$, ct al. Multiple intestinal neoplasia caused by a mutation in the murine homologue of the APC gene. Science 1992;256:668-70.

60 Dietrich WF, Lander ES, Smith JS, Moser AP, Gould KA, Luongo $\mathrm{C}$, et al. Genetic identification of MOM-1, a major modifer locus affecting min-induced intestinal meoplasia in the mouse. Cell 1993;75:631-9.

61 MacPhee M, Chepenik KP, Liddell RA, Nelson KK, Siracusa $L D$, Buchberg $A M$. The secretory phospholipase A2 gene is a candidate for the MOM-1 locus, a major A2 gene is a candidate for the MOM-1 locus, a major
modifier of APC 1995;81:957-66.
62 Thliveris A, Samowitz W, Matsunami N, Groden J, White $R$. Demonstration of promoter activity and alternative splicing in the region $5^{\prime}$ to exon 1 of the APC gene. Cancer Res 1994;54:2991-5.

63 Joslyn G, Richardson DS, White R, Alber T. Dimer formation by an N-terminal coiled coil in the APC protein. Proc Natl Acad Sci USA 1993;90:11109-13.

64 Su K-L, Johnson KA, Smith KJ, Hill DE, Vogelstein B, Kinzler KW. Association between wild type and mutant APC gene products. Cancer Res 1993a;53:2728-31.

65 Smith KJ, Johnson KA, Bryan TM, Hill DE, Markowitz $\mathrm{S}$, Willson JKV, et al. The APC gene product in normal and tumour cells. Proc Natl Acad Sci USA 1993;90: 2846-50.

66 Cohen C, Parry DAD. $x$-helical coiled coils-a widespread motif in proteins. TIBS 1986;11:245-8.

67 Rubinfeld B, Souza B, Albert I, Müller O, Chamberlain SH, Masiarz FR, et al. Association of the APC gene product with $\beta$-catenin. Science 1993;262:1731-4.

68 Su L-K, Vogelstein B, Kinzler KW. Association of the APC tumour suppressor protein with catenins. Science 1993b; 262:1734-7.

69 Polakis P. Mutations in the APC gene and their implications for protein structure and function. Curr Opin Genet Dev 1995;5:66-71.

70 Peifer M. Cancer, catenins, and cuticle pattern: A complex connection. Science 1993;262:1667-8.

71 Smith KJ, Levy DB, Maupin P, Pollard TD, Vogelstein B, Kinzler KW. Wild-type but not mutant APC associates with the microtubule cytoskeleton. Cancer Res 1994;54 3672-5.

72 Munemitsu S, Souza B, Muller O, Albert I, Rubinfeld $\mathrm{B}$, Polakis P. The Apc gene product associates with microtubules in vivo and promotes their assembly in vitro. Cancer Res 1994;54:3676-81.

73 Vasen HFA, Mecklin J-P, Meera Khan P, Lunch HT. The International Collaborative Group on hereditary nonpolyposis colorectal cancer (ICG-HNPCC). Dis Colon Rectum 1991;34:424-5.

74 Mecklin J-P, Jarvinen HJ. Tumor spectrum in cancer family syndrome (hereditary nonpolyposis colorectal cancer) Cancer 1991;68:1109-12.

75 Hall NR, Williams MAT, Murday VA, Newton JA, Bishop DT. Muir-Torre syndrome: A variant of the cancer family syndrome. $\mathcal{F}$ Med Genet 1994;31:627-31.

76 Peltomaki P, Aaltonen LA, Sistonen P, Pylkkanen L, Mecklin J-P, Jarvinen H, et al. Genetic mapping of a locus predisposing to human colorectal cancer. Science 1993; 260:810-12.

77 Lindblom A, Tannergard P, Nordenskjold W, Nordenskjold M. Genetic mapping of a second locus predisposing to hereditary non-polyposis colon cancer. Nature Genet 1993;5:279-82.

78 Nystrom-Lahti $M$, Parsons R, Sistonen P, Pylkkanen L, Aaltonen LA, Leach FS, et al. Mismatch repair genes on chromosomes $2 \mathrm{p}$ and $3 \mathrm{p}$ account for a major share of hereditary nonpolyposis colorectal cancer families evaluable by linkage. Am f Hum Genet 1994;55:659-65.

79 Aaltonen LA, Peltomaki P, Leach F, Sistonen P, Pylkkanen SM, Mecklin J-P, et al. Clues to the pathogenesis of familial colorectal cancer. Science 1993;260:812-16.

80 Fishel R, Kolodner RD. Identification of mismatch repair genes and their role in the development of cancer. Curr Opin Genet Dev 1995;5:382-95.

81 Strand M, Prolla TA, Liskay RM, Petes TD. Destabilization of tracts of simple repetitive DNA in yeast by mutations affecting DNA mismatch repair. Nature 1993;365:274-6.

82 Fishel R, Lescoe MK, Rao MRS, Copeland NG, Jenkins NA, Garber J, et al. The human mutator gene homolog $\mathrm{MSH} 2$ and its association with hereditary nonpolyposis colon cancer. Cell 1993;75:1027-38.

83 Leach FS, Nicolaides NC, Papadopoulos N, Liu B, Jen J, Parsons $\mathrm{R}$, et al. Mutations of a MutS homolog in Parsons R, et al. Mutations of a MutS homolog in 1215-25.

84 Bronner CE, Baker SM, Morrison PT, Warren G, Smith LG, Lescoe MK, et al. Mutation in the DNA mismatch repair gene homologue hMLH1 is associated with hereditary non-polyposis colon cancer. Nature 1994;368 258-61.

85 Papadopoulos N, Nicolaides NC, Wei Y-F, Ruben SM, Carter KC, Rosen WA, et al. Mutation of a mutL homolog in hereditary colon cancer. Science 1994;263:1625-9.

86 Nicolaides NC, Papadopoulos N, Liu B, Wei Y-F, Carter KC, Ruben SM, et al. Mutations of two PMS homologues in hereditary nonpolyposis colon cancer. Nature 1994; in heredita

87 Kolodner RD, Hall NR, Lipford J, Kane MF, Rao,MRS, Morrison P, et al. Structure of the human MSH2 locus and analysis of two Muir-Torre kindreds for $\mathrm{msh} 2$ mutations. Genomics 1995;24:516-26.

88 Han H-J, Maruyama M, Baba S, Park J-G, Nakamura Y. Genomic structure of human mismatch repair gene, $\mathrm{hMLH} 1$, and its mutation analysis in patients with hereditary non-polyposis colorectal cancer (HNPCC). Human Molecular Genetics 1995;4:237-42.

89 Wijnen J, Vasen H, Meera Khan P, Menko FH, van der Klift $\mathrm{H}$, van Leeuwen $\mathrm{C}$, et al. Seven new mutations in hMSH2, and HNPCC gene, identified by denaturing gradient-gel electrophoresis. Am f Hum Genet 1995;56: gradient-gel.

90 Froggatt NJ, Joyce JA, Davies R, Evans DGR, Ponder BAJ, 
Barton DE, Maher ER. A frequent hMSH2 mutation in hereditary non-polyposis colon cancer syndrome (letter) Lancet 1995;345:727.

91 Knudson AG. Mutation and cancer: statistical study of retinoblastoma. Proc Natl Acad Sci USA 1971;68:820-3.

92 Liu B, Parsons RE, Hamilton SR, Petersen GM, Lynch HT, Watson P, et al. hMSH2 mutations in hereditary nonpolyposis colorectal cancer kindreds. Cancer Res 1994;54:4590-4.

93 Parsons R, Li G-M, Longley MJ, Fang W-H, Papadopoulos $\mathrm{N}$, Jen J, et al. Hypermutability and mismatch repair Pells. Cell 1993;75:1227-36.

94 Umar A, Boyer JC, Thomas DC, Nguyen DC, Risinger $\mathrm{JI}$, Boyd J, et al. Defective mismatch repair in extracts of colorectal and endometrial cancer cell lines exhibitin microsatellite instability. $\mathcal{F}$ Biol Chem 1994;269:1436770.

95 Hemminki A, Peltomäki P, Mecklin J-P, Järvinen H, Salovaara R, Nyström-Lahti $M$, et al. Loss of the wild type MLH1 gene is a feature of hereditary nonpolyposis colorectal cancer. Nature Genet 1994;8:404-10.

96 Bhattacharyya NP, Skandalis A, Ganesh A, Groden J, Meuth M. Mutator phenotype in human colorectal carcinoma cell lines. Proc Natl Acad Sci USA 1994;91. 6319-23.

97 Lazar V, Grandjouan S, Bognel C, Couturier D, Rougier $\mathrm{P}$, Bellet $\mathrm{D}$, et al. Accumulation of multiple mutation in tumour suppressor genes during colorectal tumori- genesis in HNPCC patients. Human Molecular Genetics 1994;3:2257-60

98 Ionov Y, Peinado MA, Malkbosyan S, Shibata D, Peruch $M$. Ubiquitous somatic mutations in simple repeated sequences reveal a new mechanism for colonic carcinogenesis. Nature 1993;363:558-61.

99 Thibodeau SN, Bren G, Schaid D. Microsatellite instability in cancer of the proximal colon. Science 1993;260:81619.

100 Lothe RA, Peltomäki P, Melting GI, Aaltonen LA, Nyström-Lahti M, Pylkkänen L. Genomic instability in colorectal cancer: relationship to clinicopathological variables and family history. Cancer Res 1993;53:5849-52.

101 Shibata S, Peinado MA, Ionov Y, Malkhosyan S, Perucho $M$. Genomic instability in repeated sequences is an early somatic event in colorectal tumorigenesis that persists after transformation. Nature Genet 1994;6:273-81.

102 Young J, Leggett B, Gustafson C, Ward M, Searle J, Thomas L, et al. Genomic instability occurs in colorectal carcinomas but not in adenomas. Human Mutations 1993 . 2:351-4.

103 Young J, Searle J, Buttenshaw R, Thomas L, Ward M, Chenevix-Trench G, et al. An Alu BpA marker on chromosome 1 demonstrates that replication errors manifest at the adenomacarcinoma transition in sporadic colorectal tumors. Genes Chromosom Cancer 1995;12:251-4 104 Liu B, Farrington SM, Petersen GM, Hamilton SR, Parsons R, Papadopoulos N. Nature Med 1995;1:348-52. 